\title{
Guodong Xu
}

\author{
Uniwersytet w Xiamen (Chiny)
}

\section{RECEPCJA I NAUCZANIE PRAWA RZYMSKIEGO W CHINACH*}

\section{RECEPCJA PRAWA RZYMSKIEGO W CHINACH: NAUCZANIE I LEGISLACJA}

Mimo że zachodni misjonarze zaczęli przybywać do Chin w czasach dynastii Ming przywożąc ze sobą różne informacje dotyczące swoich krajów (na przykład misjonarz belgijski Jean-Nicolas Smogolenski przywiózł do Chin 7000 książek w językach zachodnich), nie ma pewności, że były wśród nich teksty dotyczące prawa rzymskiego. Najstarszą wzmianką o prawie rzymskim w źródłach chińskich, o ile wiem, jest raport pięciu ministrów, którzy zostali wysłani przez rząd dynastii Qing w celu zbadania systemów prawnych państw zachodnich. 9 maja 1906 r. Zaize i jego współpracownicy przekazali w swoim Raporcie dotyczącym ogólnej sytuacji prawnej we Francji, że: „Systemy polityczne państw zachodnich wywodzą się zasadniczo ze starożytnego ustroju ludu rzymskiego, a zatem osoby, które chcą zajmować się naukami politycznymi lub prawem, muszą najpierw zając się Rzymem, tak jak naukowcy chińscy muszą najpierw przestudiować dzieje Dynastii Zhou i Qin. Francja jest bliska Rzymowi w sensie geograficznym i odziedziczyła po Rzymianach bogactwo ich życia politycznego i systemu prawa. Poza tym, Napoleon I, dzięki swojemu talentowi i wypracowanej strategii, sam ustanowił ustawy niezbędne

\footnotetext{
* Tłumaczenie: Anna Tarwacka
} 
do wprowadzenia systemu państwowego i rządów ludu, rozdzielając wyraźnie prawa prywatne od władzy publicznej, uprawnienia niższe od wyższych". Ten raport potwierdzał pozycję prawa rzymskiego jako archetypu prawa w wielu państwach współczesnej Europy, a także pozycję Francji jako spadkobiercy prawa rzymskiego w pierwszej linii. To wyjaśnia, dlaczego później wprowadzono kurs prawa rzymskiego na pierwszym uniwersytecie w Chinach i dlaczego zatrudniano profesorów francuskich do prowadzenia go.

$\mathrm{Na}$ wyzwania stawiane przez kulturę zachodnią Chiny odpowiedziały reformami ruchu z 1898 r., który - chociaż trwał tylko 100 dni - pozostawił po sobie Wyższą Szkołę Stolicy, która była pierwszym uniwersytetem w Chinach. Prawo rzymskie jako kurs uniwersytecki miało teraz należne miejsce w Chinach. W rzeczywistości, przed powstaniem Wyższej Szkoły Stolicy, otworzono wydział w Szkole Pierwszej Klasy w Chinach Zachodnich Tianjing (później przemianowanej na Uniwersytet Oceanu Północnego w 1903, a następnie na Uniwersytet Tianjing w 1949). Ta Szkoła przyjęła pierwszy rocznik 30 studentów, którzy ukończyli studia w 1899. Prawo rzymskie było dla nich przedmiotem nadobowiązkowym. Kurs dzielił się na dwa przedmioty: Historia prawa rzymskiego i Prawo rzymskie. To jedyny znany mi przypadek podzielenia kursu prawa rzymskiego na dwa przedmioty w Chinach. Niestety, później prowadzono go bez podziału na przedmioty. Nie wiem, dlaczego przyjęto takie rozwiązanie wbrew dydaktycznej tradycji wspólnej państwom Europy kontynentalnej.

Chińczycy końca epoki Dynastii Qing utrzymywali, że siła państw zachodnich bierze się z ich prawa; dlatego jednym z kluczowych punktów reformy dążącej do okcydentalizacji musiało być wprowadzenie ich systemów prawnych. W związku z tym pojawiła się konieczność założenia szkół prawa, których powstało bardzo wiele. W 1904 r., rząd Dinastii Qing powołał pierwszy w historii Chin specjalistyczny instytut edukacji prawniczej: Szkołę Prawa i Nauk Politycznych Prowincji Zhini (dzisiejsza Prowincja Hebei). W czasie kolejnych pięciu lat założono 25 szkół prawa i nauk politycznych w Pekinie i w różnych prowincjach. Poza tym istniały wydziały prawa na sześciu uniwersytetach wielowydziałowych. Do 1909 r. istniało 47 szkół prawa i nauk po- 
litycznych w całych Chinach, na których studiowało 12282 studentów. Organizacja kursów i podręczniki w tych szkołach były wiernie wzorowane na praktyce uniwersyteckiej Japonii. Zatrudniono wielu wykładowców z Japonii, ponieważ - jak wiadomo - na wielu uniwersytetach w Japonii prowadzono w tym okresie kurs prawa rzymskiego. Według dokumentacji, w Szkole Pierwszej Klasy prowadzono kurs prawa rzymskiego w wymiarze 2 godzin tygodniowo. Minister Edukacji Dynastii Qing ustalił jednolity wykaz kursów dla wszystkich szkół prawa i nauk politycznych w całych Chinach, zgodnie z którym prawo rzymskie wykładano w pierwszym semestrze pierwszego roku studiów w wymiarze 2 godzin tygodniowo. We wszystkich szkołach obowiązkowo prowadzono zatem kurs prawa rzymskiego.

Po Rewolucji 1911 r., w maju 1912 r. Wyższa Szkoła Stolicy została przemianowana na Uniwersytet Pekiński i założono w niej wydziały literatury, nauk ścisłych, prawa, handlu, inżynierii, rolnictwa i inne. Prawo rzymskie było jednym z podstawowych kursów dla studentów wydziału prawa. Początkowo prowadzili go profesorowie francuscy $\mathrm{w}$ formie wykładów poświęconych szczegółowym tematom. Następnie katedrę przejął prof. Huang Youchang. Jego podręcznik „Prawo rzymskie i współczesność” został opublikowany przez Wydawnictwo Handlowe w 1913 r. W tym okresie wprowadzono również kurs łaciny na Uniwersytecie Pekińskim prowadzony przez prof. Gu Hongming, słynnego uczonego tego okresu. Można więc zaryzykować stwierdzenie, że Uniwersytet Pekiński był pierwszym, który prowadził kurs prawa rzymskiego, chociaż niestety nie wiemy ile godzin na niego poświęcano i czy był obowiązkowy czy fakultatywny.

Aż do dojścia do władzy partii komunistycznej w 1949/50 r. Uniwersitety, między innymi w Yenching, Tsinghua, Chaoyang, Soochow, Xiamen, Wuhan, Hunan, prowadziły obowiązkowy kurs prawa rzymskiego. Szczęśliwie dysponujemy danymi dotyczącymi nauczania prawa rzymskiego na Uniwersytecie Soochow. Obecność kursu prawa rzymskiego na tym uniwersytecie założonym przez Stany Zjednoczone może wydawać się dziwna, ale w rzeczywistości także na uniwersytetach amerykańskich wykładano w tym czasie prawo rzymskie. Według dokumentacji, w 1934 r. Wydział Prawa 
Uniwersytetu Soochow prowadził następujące kursy: prawo chińskie, współczesne prawo kontynentalne (prawo cywilne Francji, Niemiec, Japonii i Rosji sowieckiej), prawo anglosaskie, prawo rzymskie, prawo publiczne międzynarodowe i prawo prywatne międzynarodowe oraz inne. Prawo rzymskie było przedmiotem obowiązkowym dla studentów drugiego roku, trwającym przez rok dwie godziny w tygodniu. Szczególnej uwagi wymaga też obecność kursu łaciny na tym wydziale jako przedmiotu obowiązkowego zajmującego 6 godzin tygodniowo.

Na podstawie wykazu przedmiotów Wydziału Prawa Uniwersytetu Centralnego z 1934 r. wiadomo, że prawo rzymskie było wykładane jako przedmiot obowiązkowy dla studentów pierwszego roku zajmujący trzy godziny tygodniowo przez rok.

Według wspomnień prof. Xie Huaishi, słynnego cywilisty ówczesnych Chin, około 1938 r., kiedy studiował on w filii uniwersyteckiej Szkoły Centralnej Nauk Politycznych w Chongqing, uczęszczał na zajęcia z prawa rzymskiego prowadzone przez prof. Mei Zhongxie, uczonego wykształconego we Francji korzystającego z niemieckiego podręcznika. Przedmiot był obowiązkowy, trwał przez rok, dwie godziny tygodniowo.

Według archiwów Uniwersytetu w Lanzhou, udostępnionych mi dzięki uprzejmości pani prof. Fan Xiaoyu z grona naukowego tego Uniwersytetu, w okresie od 1941 do 1945, Instytut Gansu, poprzednik dzisiejszego Uniwersytetu Lanzhou prowadził kurs prawa rzymskiego, na który uczęszczały dziesiątki studentów uzyskujących doskonałe oceny.

Prawo rzymskie zostało spopularyzowane w Chinach dzięki powyższym osobom i książkom. Należy podkreślić, że w podręcznikach napisanych przez tych autorów przedstawiano zagadnienia prawa rzymskiego według układu chińskiego kodeksu cywilnego, czyli w oparciu o systematykę pandektową, w stylu niemieckim. Poza tym, chociaż autorzy ci pisali podręczniki prawa rzymskiego, nie stworzyli w tej dziedzinie żadnej monografii.

Do tej pory mówiłem o recepcji prawa rzymskiego z punktu widzenia nauczania. Teraz chciałbym powiedzieć o recepcji prawa rzymskiego z punktu widzenia legislacji. 
Po wojnach opiumowych w 1840, Chiny zostały poddane jurysdykcji zewnątrzpaństwowej przez państwa zachodnie. Żeby ją uchylić, Chiny zmuszono do wprowadzenia kodeksu cywilnego w stylu zachodnim. W sierpniu 1911 juryści dynastii Qing ukończyli z pomocą jurystów japońskich projekt kodeksu cywilnego, w którym zastosowano systematykę pandektowa, treść zaś była zgodna z prawem rzymskim. Ale dynastia niedługo później upadła i projekt ten nigdy nie został zatwierdzony. Następca polityczny dynastii Qing, Republika Chińska założona w 1911, powołała Komitet Kodyfikacyjny, który, na podstawie projektu dynastii Qing, stworzył kodeks cywilny promulgowany w latach 1929-1933. Był to pierwszy kodeks cywilny w historii prawnej Chin i nadal pozostaje on w mocy w Tajwanie. W epoce komunizmu Chiny wielokrotnie usiłowały skodyfikować prawo cywilne, ale bezskutecznie. W związku z tym, do dziś nie mamy kodeksu cywilnego w pełnym tego słowa znaczeniu.

\section{NAUCZANiE PRAWA RZYMSKIEGo W EPOCE MaO}

Od końca dynastii Qing przez cały okres Republiki Chińskiej, kontynentalny model prawny ugruntował się w Chinach. W 1949, kiedy oddziały komunistyczne i nacjonalistyczne spotkały się twarzą w twarz nad rzeką Jangcy, przywódca Partii nacjonalistycznej zaproponował zawarcie pokoju, jednym z warunków którego było zachowanie narodowej kultury prawnej. Ta propozycja została bezwzględnie odrzucona przez Mao Zedonga, przywódcę Partii Komunistycznej. Dlatego, po wygnaniu nacjonalistów na Tajwan przez komunistów, corpus 6 kodeksów przez nich wprowadzonych został wycofany. W zgodzie $\mathrm{z}$ ideologią komunistyczną, należało zniszczyć cały mechanizm dawnego państwa i jego ideologii, aby stworzyć całkiem nowe państwo. Będąc częścią danej kultury prawnej, nauczanie prawa rzymskiego znajdowało się rzecz jasna w obliczu kryzysu. Zostało ono rzeczywiście wycofane na pewien czas, a Chiny zwróciły się w kierunku Rosji sowieckiej, aby poznać zasady edukacji prawniczej. Plan zajęć Wydziału Prawa, wprowadzony przez Ministerstwo Kształcenia Publicznego w 1951, przewidywał wykazywanie zaawansowania i wyższości nowego reżimu prawnego jako 
podstawową wartość wszystkich kursów. Jeśli chodzi o ich podstawy teoretyczne i bibliografię, marksizmo-leninizm i myśl Mao Zedonga miały służyć za główne kierunki nauczania, należało też stosować podręczniki i inne książki akademickie z ZSRR jako pomoce wspierające nauczanie. Według jednolitego wykazu kursów dla studentów nauk prawnych wprowadzonego przez Ministerstwo Kształcenia Publicznego w 1953 r., na wydziałach wykładano wtedy następujące przedmioty: historia państwa i prawa ZSRR, sowieckie prawo polityczne, prawo ziemi i prawo kołchozów, prawo krajów demokracji ludowej, prawo organizacji trybunałów Chin i ZSRR, prawo procesowe Chin i ZSRR, prawo pracy Chin i ZSRR, prawo administracyjne Chin i ZSRR, prawo finansowe Chin i ZSRR. W latach 1952-1956, przetłumaczono w Chinach 165 radzieckich podręczników prawniczych. Jest oczywiste, że prawo rzymskie wykluczone było zarówno z tych kursów, jak i podręczników. Z dzisiejszego punktu widzenia, za taką sytuację nie da się winić ZSRR, ponieważ, mimo że początkowo zniesiono tam nauczanie prawa rzymskiego po 1917, to jednak potem je przywrócono w 1944 r. pod koniec drugiej wojny światowej. Właśnie w tym czasie prof. Jiangping rozpoczynał kontakt z prawem rzymskim na Uniwersytecie Moskiewskim. Studiował na Wydziale Prawa tego uniwersytetu w latach 1951-1956, gdzie prawo rzymskie było jednym z przedmiotów nadobowiązkowych zajmującym 32 godziny. To doświadczenie akademickie spowodowało, że prof. Jiangping został w późniejszym okresie profesorem prawa rzymskiego. Radziecka metoda organizowania kursu prawa rzymskiego została ponadto całkowicie przeniesiona do Chin.

Jednak przed 1957 r. Chiny odmawiały powtórzenia reformy radzieckiej w tym względzie. W 1957 ówczesny kierownik Ministerstwa Kształcenia Publicznego, Xiufeng, który studiował socjologię i pedagogikę we Francji, i rektor Uniwersytetu Pekińskiego Ma Yingchu zaczęli przemyśliwać problem wprowadzenia nauczania prawa rzymskiego na tym uniwersytecie. Wynikało to zapewne z ich doświadczeń ze studiów w państwach zachodnich oraz ze zmiany nastawienia ZSRR wobec prawa rzymskiego. Byli oni przekonani, że na uniwersytecie powinno się prowadzić tradycyjne kursy z tego przedmiotu. 
Żeby urzeczywistnić swój pomysł, szukali informacji u byłych nauczycieli prawa rzymskiego w 1958, ale - ponieważ uważali, że ci jako wychowani w reżimie nacjonalistycznym, mieli zbyt starodawne poglądy - wybrali spośród młodych absolwentów Xie Bangyu, który ukończył Uniwersytet Pekiński, przydzielając mu jako opiekuna prof. Rui Mo, który studiował w Niemczech. Aby dobrze wykształcić tego pierwszego romanistę nowych Chin, Ministerstwo Kształcenia Publicznego i Uniwersytet Pekiński postawily przed nim zadanie nauczenia się pięciu języków obcych: łaciny, angielskiego, hiszpańskiego lub portugalskiego, rosyjskiego i francuskiego. Po trzyletnich przygotowaniach 24 lutego 1962, Xie Bangyu po raz pierwszy poprowadził zajęcia z prawa rzymskiego dla 170 studentów czwartego i piątego roku oraz dla doktorantów w obecności ówczesnego rektora uniwersytetu, Lu Ping, dziekana Wydziału Prawa. To wydarzenie, bardzo istotne z punktu widzenia edukacji prawniczej, wywołało silny odzew. Na przykład, prof. Huang Youchang, który miał wówczas ponad 90 lat, i słynny ekspert $\mathrm{w}$ dziedzinie prawa międzynarodowego prof. Zhou Gengsheng chcieli przejąc obowiązki wykładowcy, a prawie 80-letni prof. N.B.Novitski z Uniwersytetu Moskiewskiego przesłał Xie Bangyu swoje dzieło „Podstawy rzymskiego prawa prywatnego" oraz program nauczania, co okazało się dla niego niezwykle przydatne. W tym czasie prawo rzymskie było przedmiotem obowiązkowym dla studentów wyższych lat i doktorantów. Ilość godzin dydaktycznych nie była ściśle ustalona, było to minimum 36, maksymalnie 48 godzin. $\mathrm{Z}$ powodu braku wykładowców przedmiot ten wykładany był jedynie na Uniwersytecie Pekińskim. Nawet tam przetrwał jedynie przez rok, a następnie został zlikwidowany w 1963. Przyczyną tej likwidacji był ówczesny nihilizm prawniczy i pogorszenie stosunków chińsko-radzieckich. W tych warunkach wszyscy wykładowcy prawa rzymskiego zmienili zawód.

$Z$ obecnego punktu widzenia przywrócenie kursu prawa rzymskiego w ZSRR i Chinach postrzegać należy przez pryzmat zimnej wojny. Wraz z końcem II wojny światowej uformowały się obozy socjalistyczny i kapitalistyczny, których naukowcy mierzyli w siebie wzajemnie teoretycznymi pociskami, tocząc zimną wojnę na polu teorii. 
Dobrym polem walki w tej wojnie były badania nad prawem rzymskim, ponieważ jeden z punktów wyjścia marksizmu, materializm historyczny, stworzony został na bazie wielu zagadnień prawa rzymskiego. Na przykład marksistowska teoria powstania państwa i prawa opierała się na doświadczeniach prawnych ludu rzymskiego. Problem jak traktować fenomeny historii prawa rzymskiego stał się zatem polem walki dla teorii naukowców z obu obozów, przekształcając prawo rzymskie w dziedzinę entuzjastycznie badaną przez wszystkich. Wydaje się, że utrzymanie kursów prawa rzymskiego w państwach socjalistycznych wynikało właśnie z konieczności zaspokojenia teoretycznych potrzeb zimnej wojny.

3. Nauczanie prawa rzymskiego w epoce Deng Xiaoping, Jiang ZeMin I Hu JinTAo

Dwa lata po śmierci Mao w 1976, Deng Xiaoping, uzyskawszy najwyższa pozycję w państwie, sformułował politykę otwartości na świat zachodni, stwarzając warunki do reformy edukacji uniwersyteckiej i prawniczej. Od tego momentu uznawano znaczenie dziedzictwa prawa rzymskiego dla ludzkości. Po 1979 r. ponownie wprowadzono kursy prawa rzymskiego w zreformowanych Instytutach Nauk Politycznych i Prawa oraz na wydziałach uniwersyteckich. Nadal posługiwano się radzieckim modelem przydzielając na prawo rzymskie 36 godzin i nadając mu charakter fakultatywny w odniesieniu do studentów. Dla doktorów, przede wszystkim dla tych specjalizujących się w historii prawa państw obcych, organizowano podobne zajęcia, ale przeznaczano na nie mniej godzin. Aby rozwiązać problem braku wykładowców prawa rzymskiego, Ministerstwo Sprawiedliwości we współpracy z Uniwersytetem Anhui, zorganizowało kurs dokształcania w dziedzinie prawa rzymskiego w 1983 w Hefei, stolicy tej prowincji. Prof. Zhounan prowadził wszystkie zajęcia dzieląc materiał na prawo osobowe, prawa rzeczowe, prawo zobowiązań, prawo procesowe, etc. Jest prawdopodobne, że nauczanie prof. Zhou na tym kursie było najbardziej technicznym i szczegółowym wykładem prawa rzymskiego w historii Chin. Na kurs uczęszczały dzie- 
siątki wykładowców pochodzących z Instytutu Nauk Politycznych i Prawa Środkowego Południa, z Uniwersytetu Jilin, z Instytutu Nauk Politycznych i Prawa Południowego Zachodu, z Uniwersytetu Anhui; wszyscy zostali potem ekspertami prawa rzymskiego w swoich ośrodkach.

Jednocześnie rozpoczęto pisanie podręczników prawa rzymskiego, aby sprostać zapotrzebowaniom nauczania. W listopadzie 1982 pojawiły się „Podstawy prawa rzymskiego” prof. Jiangping, podręcznik liczący 148 stron, w którym materiał uporząakowano według sytemu pandektystycznego pod wpływem podręcznika prawa rzymskiego N.B. Novitskiego. W kolejnym roku ukazał się 378-stronicowy jednolity podręcznik prawa rzymskiego, przeznaczony przez Ministerstwo Sprawiedliwości dla wszystkich podległych mu uniwersytetów, stworzony przez trzech profesorów Zhounan, Wu Wenhane, Xie Bangyu na podstawie rękopisu tegoż profesora Xie Bangyu dla studentów Uniwersytetu Pekińskiego. Także w nim podzielono materiał według systemu pandektowego. Podręcznik ten zawierał nieco zbyt wiele nowoczesnych elementów, w których ujawniała się wola autorów pogodzenia prawa rzymskiego z ideologią socjalistyczną. W czerwcu 1987 prof. Jiangping rozszerzył ten podręcznik przy współpracy Mijian, zwiększając jego objętość do 397 stron. W tym czasie na Uniwersytecie Anhui zdecydowano się uporządkować rękopisy dotyczące prawa rzymskiego prof. Zhounan i powołano w tym celu komisję. Po latach wysiłków, w 1994 komisja ta opublikowała tom zatytułowany „Traktat podstawowy o prawie rzymskim", który natychmiast stał się najbardziej cenionym dziełem $\mathrm{w}$ dziedzinie prawa rzymskiego w Chinach i jest bardzo często cytowany.

W badaniach romanistycznych $\mathrm{w}$ moim kraju nastapił znaczący zwrot w maju 1988, kiedy Huangfeng z Uniwersytetu Nauk Politycznych i Prawa Chin w Pekinie, który zajmował się wpółczesnym prawem karnym we Włoszech, spotkał prof. Pietrangelo Catalano z Uniwersytetu La Sapienza w Rzymie i prof. Sandro Schipani z Uniwersytetu Tor Vergata w Rzymie, dochodząc z nimi do porozumienia $\mathrm{w}$ sprawie wymiany naukowej między dwoma krajami na polu prawa rzymskiego. W związku z tym rektor prof. Jiangping, odwie- 
dził Rzym w lutym 1989, wygłaszając wykład „Stosunek Chin ludowych wobec rzymskiej kultury prawnej”. Przy okazji podpisał umowę o współpracy między Uniwersytetem Nauk Politycznych i Prawa Chin a Uniwersytetem Tor Vergata w Rzymie. Na jej podstawie wysyłał młodych naukowców do Rzymu, aby studiowali i thumaczyli wybrane fragmenty Corpus Iuris Civilis na chiński. Od tego momentu kolejno Huangfeng, Dingmei, Mijian, Fei Anling, Fan Huaijun, Xu Guodong, Zhang Lihong i Liu Jiaan, Xuejun i inni, prowadzili badania na Uniwersytecie Tor Vergata w Rzymie pod kierunkiem prof. Aldo Petrucci i doktora Giuseppe Terracina.

Po powrocie do Chin ci młodzi naukowcy zostawali zwykle wykładowcami prawa rzymskiego. Stworzyli oni nowe pokolenie nauczycieli tego przedmiotu. Ich wyjątkowość polega na tym, że wszyscy znają łacinę, co pozwala im bezpośrednio zajmować się tekstami źródłowymi. W ramach tej współpracy przetłumaczono także i rozpowszechniono w Chinach znakomite dzieła włoskie dotyczące prawa rzymskiego, takie jak „Intytucje prawa rzymskiego” autorstwa Bonfante i ,Historia prawa rzymskiego" Grosso. Dzieła te pozwoliły chińskim uczonym poznać system nauczania prawa rzymskiego we Włoszech, na przykład podział na dwa przedmioty: instytucje i historię prawa rzymskiego. Pozwoliły również dowiedzieć się o istnieniu rzymskiego prawa publicznego i jego zalet. Przede wszystkim jednak opublikowano dwanaście części Corporis Iuris Civilis Fragmenta Selecta, chińskich przekładów Instytucji Gaiusa i Justyniana zawierających również tekst łaciński.

Poza źródłami prawniczymi przetłumaczono i opublikowano również niektóre źródła literackie: De re publica, De legibus, De officiis, De oratore Cycerona. W latach 1994 i 1999 zorganizowano w Chinach dwa międzynarodowe kongresy prawa rzymskiego. Ukazały się także romanistyczne monografie Dingmei i Fei Anling. W 2002 r. powstało czasopismo dotyczące prawa rzymskiego. Do tej pory ukazało się pięć numerów. Badania nad prawem rzymskim w Chinach wkroczyły zatem w nowy etap, najlepszy w dotychczasowej historii. Mijian, we współpracy z prof. Knütel z Uniwersytetu w Bonn, przetłumaczył też siódmą księgę Digestów i opublikował ją pod tytułem Ususfructus. 
Wkład Włochów i Niemców w edukację w dziedzinie prawa rzymskiego w Chinach spowodował wspaniałe rezultaty w postaci zwiększenia ilości przetłumaczonych źródeł i stanowił bodziec do badań naukowych, ale jego wpływ na organizację nauczania był niewielki. Proszę pozwolić mi wyjaśnić kilka kwestii w świetle przykładów: (1) Większość uniwersytetów chińskich nadal prowadzi tylko jeden kurs prawa rzymskiego, który dotyczy jedynie prawa prywatnego, wykluczając prawo publiczne. Jedynie zatem nieliczni studenci wiedzą o istnieniu i znaczeniu tej gałęzi prawa. Mamy więc nadzieję na pojawienie się w Chinach podziału systemu dydaktycznego na instytucje i historię prawa rzymskiego, przy czym ten drugi przedmiot powinien zawierać również zagadnienia prawa publicznego; (2) ilość godzin dydaktycznych prawa rzymskiego nadal powiela tradycję sprzed 50 lat i wynosi 36 godzin uniemożliwiając całościowe omówienie nawet prawa prywatnego w tak krótkim czasie; (3) mimo że Włosi zorganizowali tłumaczenie wielu źródeł prawa rzymskiego, nie rozpoczęto jeszcze tworzenia nowych podręczników. Istniejące podręczniki powstały w początkach ery Deng Xiaoping, i nie zaspokajają już aktualnych potrzeb. Z powodu braku nowych podręczników trzeba było korzystać z Instytucji justyniańskich jako podręcznika na Uniwersytecie Nauk Politycznych i Prawa Chin w Pekinie; (4) Wykładowcy prawa rzymskiego $\mathrm{z}$ wielu uniwersytetów wykształceni przez prof. Zhounan, nie mają przygotowania do egzegezy tekstów źródłowych. $Z$ drugiej strony wykładowcy wykształceni we Włoszech nie zaczelli jeszcze kształcić kolejnych. Zatem problem braku wykładowców i ich słabego przygotowania jest jeszcze bardzo poważny.

Normy Narodowego Standardu Wyższego Wykształcenia Profesjonalnego Federacji Rosyjskiej przyjętego w marcu 2000 r. zaoferowały Uniwersytetowi w Xiamen plan reformy nauczania prawa rzymskiego, zgodnie z którym kurs ten powinien zostać podzielony na dwa przedmioty: prywatne prawo rzymskie $\mathrm{i}$ historię prawa rzymskiego i obejmować łącznie 100 godzin dydaktycznych. Dziekan wydziału go poparł i plan został wdrożony. Powiodły się także moje starania o zmianę nazwy przedmiotu z kursu prawa rzymskiego na kurs rzymskiego prawa prywatnego, co bardziej odpowiada jego treści. 


\section{WNIOSKI I PERSPEKTYWY}

Moim zdaniem, jeśli potraktować rozpoczęcie kontaktów akademickich między romanistami chińskimi i włoskimi jako linię graniczną, w nauczaniu prawa rzymskiego w Chinach zaszły następujące zmiany:

- Z drugiej ręki do pierwszej ręki. Początkowo nauczanie prawa rzymskiego nie było oparte na tekstach źródłowych, ale na dziełach naukowców francuskich, belgijskich i japońskich; poza tym żaden romanista chiński nie studiował ani nie prowadził badań naukowych w państwie, w którym narodziło się prawo rzymskie, czyli we Włoszech. Później ta sytuacja uległa zmianie i romaniści chińscy zaczęli studiować prawo rzymskie na podstawie źródeł i we Włoszech. Wzrost dostępności źródeł spowodował, że młodzi naukowcy przyzwyczajają się do korzystania z metody egzegezy używając Instytucji justyniańskich jako podręcznika kursowego. O ile wcześniej metodą nauczania prawa rzymskiego była dedukcja, obecnie jest to indukcja.

- Od prawa rzymskiego prywatnego do prawa rzymskiego sensu largo. Początkowo chińscy naukowcy byli przekonani, że prawo rzymskie to jedynie prawo prywatne, przede wszystkim prawo procesowe. Rzecz jasna zdawano sobie sprawę z istnienia rzymskiego prawa publicznego, ale uznawano, że nie przedstawiało ono żadnej wartości. Zmiana nastawienia do prawa publicznego spowodowała poświęcenie mu badań i stworzenie przekładów źródeł.

- Od nauczania do badań naukowych. Początkowo aktywność naukowa w dziedzinie prawa rzymskiego w Chinach ograniczała się do nauczania, a wszystkie publikacje w tym zakresie były podręcznikami. Później chińscy romaniści zaczęli zajmować się nie tylko nauczaniem, ale i prowadzeniem badań naukowych. Ukazały się cztery monografie z dziedziny prawa rzymskiego: „Odpowiedzialność kontraktowa w prawie rzymskim” Dingmei, „Studium z zakresu sukcesji w prawie rzymskim” Fei Anling, ,Wprowadzenie do rzymskiego prawa prywatnego" i mój ,Traktat elementarny z zakresu rzymskiego prawa prywatnego - teksty i analizy"

- przejście od izolacji do otwarcia się na wymianę: nie posiadamy dokumentów, które by wskazywały na istnienie wcześniejszej mię- 
dzynarodowej wymiany naukowców w dziedzinie prawa rzymskiego, obecnie chińscy romaniści uczestniczą $\mathrm{w}$ wielu programach międzynarodowej wymiany nauczycieli akademickich i w projektach badawczych realizowanych we Włoszech, w krajach Europy Wschodniej i Ameryki Łacińskiej;

- przejście od podejścia ideologicznego do technicznego: kiedyś, przede wszystkim w epoce Mao, prawo rzymskie było postrzegane jako ideologia burżuazyjna i używane jako instrument w ideologicznej ,zimnej wojnie”, obecnie jest postrzegane jako zespół wartości ideologicznie neutralnych, który może być wykorzystywany niezależnie od preferowanej ideologii;

- przejście od systematyki pandektowej do systematyki instytucji: kiedyś wszystkie podręczniki do prawa rzymskiego były oparte na systematyce niemieckich pandektów, obecnie, mimo, iż nie ukazał się jeszcze nowy podręcznik do prawa rzymskiego, idee naukowców są odmienne i taki podręcznik, jeżeli powstanie, będzie odwzorowywał system antycznych Institutiones zgodnie z oczekiwaniami stawianymi komitetowi redakcyjnemu opracowującemu przyszły model nauczania;

- przejście od wykładu fakultatywnego do obowiązkowego i jednocześnie redukcja godzin nauczania na rzecz podniesienia jakości i efektywności kursu: nauczanie prawa rzymskiego przeżyło kryzys w Chinach. Kiedyś przed 1949 r. kurs tego prawa był obowiązkowy w wymiarze 108-172 godzin. W epoce Deng Xiaopinga, Jing Zemin i Hu Jintao stał się kursem nieobowiązkowym prowadzonym w wymiarze 32-36 godzin, co być może odzwierciedla zamierzenia rządu chińskiego w kierunku reformowania systemu nauczania uniwersyteckiego w sensie pragmatycznym. 